\title{
Clinical cardiac alterations and hemostatic toxicities caused by scorpion (Tityus discrepams) venom and its purified fractions on zebrafish (Damio rerio) larvae.
}

\author{
Aurora M. Álvarez, 1 , Marco Álvares², Lourdes Perdomo ${ }^{2}$ and Alexis Rodríguez-Acosta ${ }^{3}$ \\ ${ }^{1}$ Centro de Biociencias y Medicina Molecular, Instituto de Estudios Avanzados (IDEA), \\ Caracas, República Bolivariana de Venezuela. \\ ${ }^{2}$ Laboratorio de Microscopia Electrónica, Instituto Anatómico "José Izquierdo" \\ de la Universidad Central de Venezuela, Caracas, República Bolivariana de Venezuela. \\ ${ }^{3}$ Laboratorio de Inmunoquímica y Ultraestructura, Instituto Anatómico "José Izquierdo" \\ de la Universidad Central de Venezuela, Caracas, República Bolivariana de Venezuela.
}

Key words: cardiotoxicity; Danio rerio; scorpions; Tityus discrepans; venom; zebrafish.

\begin{abstract}
Envenomation by the Venezuelan scorpion Tityus discrepans is typified by local and systemic alterations. The current work investigated the in vivo hemostatic processes, cardiac dysfunction and tissue destruction triggered by Tityus discrepans purified toxins $1(3 \mathrm{kDa})$ and $2(5 \mathrm{kDa})$ fractions. These fractions were obtained by C-18-HPLC chromatography. The hemostatic and cardiovascular toxicities in zebrafish of both fractions was assessed by means of specific phenotypic expressions and larvae behavior at 5, 15, 30, 40 and $60 \mathrm{~min}$ post-venom-treatment. The Tityus discrepans venom fractions 1 and 2 produced disseminated intravascular coagulation (presence of thrombus) in the central vein of the larva, heart rate/rhythm alterations, and necrotic events in more than $90 \%$ of all the larvae under their action. The outcomes have established the potential hemostatic and cardiovascular toxicities by Tityus discrepans venom, alerting on the possibility of cardiovascular injuries and thromboembolism in humans after scorpion stings envenomation.
\end{abstract}




\section{Alteraciones clinicas cardiológicas y toxicidades hemostáticas causadas por el veneno del escorpión (Tityus discrepans) y sus fracciones purificadas en las larvas del pez cebra (Danio rerio).} Invest Clin 2021; 62 (4): 325-338

Palabras clave: cardiotoxicidad; Danio rerio; escorpión; pez cebra; Tityus discrepans; veneno.

Resumen. El envenenamiento por el escorpión venezolano Tityus discrepans se caracteriza por alteraciones locales y sistémicas. El trabajo actual investigó los procesos hemostáticos in vivo, la disfunción cardíaca y la destrucción tisular desencadenada por las fracciones de toxinas $1(3 \mathrm{kDa})$ y $2(5 \mathrm{kDa})$ purificadas. Estas fracciones se obtuvieron mediante cromatografía C-18-HPLC. La toxicidad hemostática y cardiovascular en el pez cebra de ambas fracciones se evaluó mediante expresiones fenotípicas específicas y comportamiento de las larvas a $\operatorname{los} 5,15,30,40$ y 60 min post-tratamiento con veneno. Las fracciones 1 y 2 del veneno de Tityus discrepans produjeron coagulación intravascular diseminada (presencia de trombos) en la vena central de la larva, alteraciones de la frecuencia/ritmo cardíaco y eventos necróticos en más del $90 \%$ de todas las larvas bajo su acción. Los resultados han establecido las posibles toxicidades hemostáticas y cardiovasculares del veneno de Tityus discrepans, advirtiendo la posibilidad de lesiones cardiovasculares y tromboembolismo en humanos después del envenenamiento por picaduras de escorpiones.

Received: 23-04-2021 Accepted: 09-09-2021

\section{INTRODUCTION}

Scorpion envenomation is a Collective Health problem in numerous countries in the tropics and subtropics geographical regions, with important mortality in the severe forms producing numerous organ collapses. No other than scorpions of the Tityus genus are of medical significance in Venezuela, and Tityus discrepans is responsible for the most severe cases of envenomation and deceases.

On the other hand, during the last years, zebrafish has become the most relevant biological model among vertebrates, after the mouse (1). It has been judged as a vertebrate experimental model for the study of developmental biology and genetics. The zebrafish is a member of the Danio genus (Cyprinidae family). Experimentation in zebrafish has demonstrated that most of the important biological processes are highly analogous between this species and mammals. Amid the correspondences is already known that the zebrafish genome is highly similar to the human genome, with approximately $87 \%$ similarity and also the type of proteins used to form diverse portions of the body (2). The anatomical, physiological (including the coagulation system) and molecular physiology ranks, which explicates the achievement of the zebrafish as a biological model in disparity to other species (2). Toxin binding sites are generally well conserved 
between zebrafish and man; the cardiovascular, nervous systems and metabolic pathways are extremely comparable with the anatomical, physiological and molecular aspects of mammals; their pharmacological reaction is analogous to humans, being useful in the identification of theoretically therapeutic tests $(3,4)$. Likewise, zebrafish permits obtaining a high quality recognition of target substances and a validation in vivo of these constituents during clinical trials in humans (5).

In the present work, we have explored this specific vertebrate model to evaluate the toxicity of relevant toxins of the scorpion (Tityus discrepans), through the observation of the adverse effects to their exposure, identifying the end point of toxicity, mechanisms of toxicity and the determination of the toxic-dynamics of toxins, among others (6). Here, we have estimated the cardiovascular system of the zebrafish, a significant guide to toxicity, since the venom fractions caused simply observable effects, such as the alterations in the circulation of blood flow (thrombosis), the heart rate rhythmicity, the cardiac output, the cardiac morphology, the pericardial morphology, among others. These results provided rapid, reproducible and quantifiable information (7).

\section{MATERIALS AND METHODS}

\section{Reagents}

Chemicals and reagents used in this research were obtained from Sigma-Aldrich Co. (St Louis, MO, USA), Thermo Fisher Scientific (Waltham, MA, USA), and BD Biosciences (San Jose, CA, USA). Low-range "rainbow" molecular mass markers (38 to 3,5 kDa) were purchased from Amersham; GE healthcare companies, USA.

\section{Mice}

Male mice (Mus musculus) C57/BL6 strain weighing 20 to 22 grams (g), from the vivarium of the Instituto de Estudios Avan- zados (IDEA), were used to determine lethal activity $\left(\mathrm{LD}_{50}\right)$. Animals were supplied with water and food ad libitum, until use.

\section{Scorpions Tityus discrepans and venom collection}

A pool of venoms was obtained from 42 scorpions specimens kept in captivity, hydrated with distilled water and fed with caeliferous larvae (grasshoppers). These scorpions come from the vicinity of the municipality El Hatillo, Los Salías (Fire Department) and Baruta (Hoyo de la Puerta), Miranda state, Venezuela. The scorpion's ecological area is situated in a climatic bioregion of humid forest, located $1200 \mathrm{~m}$ up of sea level, with an average annual temperature of $21^{\circ} \mathrm{C}$ and relative humidity of $85 \%$ or more. The flora is represented for an exuberant vegetation of humid forest formation (8).

The Tityus discrepans scorpion venoms were collected and pooled in the Vivarium of the Instituto de Estudios Avanzados (IDEA), (Miranda state, Venezuela). They were manually milked by electrical stimulation of the telson. Two electrodes connected to a stimulator (SD5-Grass ${ }^{\mathrm{TM}}$ ) were placed; one at the base of the aculeus and the other on a pedipalp. The contact area of the scorpion was humidified and got in touch with the electrodes. Three electric pulse trains with a frequency of 6/pps, duration of $100 \mathrm{~ms}$, and 60-volt intensity were applied (SD5-Grass ${ }^{\text {тм }}$ : SM6-stimulator Gras Model = GM6, signal M2010x5, Instrument CO, Quincy Miss, USA).

The ejected venom was collected in non-heparinized capillary tubes and transferred to Eppendorf tubes, where it was resuspended with 18 -megaOhm water by constant vortexing for 30 seconds (s) and centrifuged at $20.000 \mathrm{~g}$ in a refrigerated $\left(5^{\circ} \mathrm{C}\right)$ centrifuge (Eppendorf 5417R) for 5 min. Then, the supernatant was filtered using $0.22 \mu \mathrm{m}$ millex-GS. It was labelled with the date, group and number of milked scorpions. 
Protein concentration of the scorpion Tityus discrepans venom by bicinchoninic acid method

The Tityus discrepans venom protein concentration was measured by the bicinchoninic acid (BCA) method (BCA ${ }^{\mathrm{TM}}$ Protein Assay Kit, Pierce, Illinois, USA) kit.

The procedure was carried out in 96well culture plates, adding $25 \mu \mathrm{L}$ of the samples from both the standard curve and the test sample, plus $200 \mu \mathrm{L}$ of the BCA reagent (prepared as indicated by the commercial company: 50 parts of reagent $A$ with a part of reagent $\mathrm{B})$. The plate was shaken, while incubated at $37^{\circ} \mathrm{C}$ for $30 \mathrm{~min}$. Finally, the plate was allowed to cool for $5 \mathrm{~min}$ at room temperature and the absorbance at $562 \mathrm{~nm}$ was measured with the ELISA reader (Biotek, Synergy ${ }^{\mathrm{TM}}$ model, USA).

\section{Protein determination from fractions 1 and 2 of the Tityus discrepans venom}

Protein concentration of 1 and 2 fractions were spectrophotometrically estimated by assuming that $1 \mathrm{U}$ of absorbance/em of wavelength at $280 \mathrm{~nm}$ corresponds to $1 \mathrm{mg}$ protein/mL (9).

\section{Determination of Lethal Dose Fifty $\left(\mathrm{LD}_{50}\right)$}

The $\mathrm{LD}_{50}$ for Tityus discrepans crude venom was determined ( $48 \mathrm{~h}$ ) by intraperitoneally (i.p.) venom injection in mice (18$22 \mathrm{~g}$ ) and calculated according to the Spearman-Kärber method (10). Five mice per dose $(4.5 \mathrm{mg} / \mathrm{kg}$ to $1.25 \mathrm{mg} / \mathrm{kg})$ were used. These doses were selected on basis of the previous reports of lethality of the Tityus discrepans crude venom in our laboratory (11). The $\mathrm{LD}_{50}$ tests from fractions 1 and 2 were not carried out, since the test required significant quantities of fractions and we have not the necessary amount of these fractions.

\section{Ethical statement}

Expert personnel set all the experimental techniques concerning the use of live animals, including zebrafish embryos, larvae, juveniles, adults and scorpions. Venezuelan pertinent regulations as well as institutional guidelines, according to protocols ratified by the Institute of Anatomy Ethical Committee of the Universidad Central de Venezuela in accordance with the ethical principles in animal research adopted by the World Health Organization (12).

\section{Fractionation of the scorpion Tityus discrepans venom by HPLC}

The Tityus discrepans venom (2 mg) was fractionated using the high-resolution chromatography method (HPLC). A Zorbox 3000SB-C18 chromatographic column was used as the separating matrix. The proteins were eluted off the column at room temperature with an acetonitrile linear gradient of $0 \%-80 \%(\mathrm{v} / \mathrm{v})$ in $0.12 \% \mathrm{TFA}$ for $60 \mathrm{~min}$. A Waters 1525 binary HPLC pumps with a Waters 2487 dual $\mathrm{k}$ absorbance detector (280 $\mathrm{nm})$ were employed. Samples for biological assays were lyophilized twice to remove potential trace amounts of solvent. Ten different HPLC runs were performed keeping the same conditions. The fractions were collected at $1.5 \mathrm{~mL} /$ tube. All fractions were tested for any activity on the larvae (type of movement, presence or not of paralysis, blood flow characteristics and/or death).

In the well-defined fractions could be observed the fractions 14 and 55, with retention times of $11.87 \mathrm{~min}$ and $25.58 \mathrm{~min}$, respectively, which showed the highest activity and purity. They were dialyzed against water at $4^{\circ} \mathrm{C}$ and lyophilized to perform the subsequent assays in the zebrafish model.

\section{Gel electrophoresis}

Polyacrylamide gel (15\%) electrophoresis following the (13) method was used to determine the Tityus discrepans venom besides 1 and 2 fractions molecular masses.

The lyophilized venom was reconstituted in denaturing buffer (10mM Tris-HCl, $2 \%$ SDS, 0.1M DTT, 0.01\% blue bromophenol, and $1 \mathrm{mM}$ EDTA, $\mathrm{pH} 8.0$ ). Low-range "rainbow" molecular mass markers (38.0 to 3.5 $\mathrm{kDa}$ ) were used as reference for SDS elec- 
trophoresis. Proteins were stained with Coomassie blue stain.

\section{Breeding of zebrafish (Damio rerio) larvae}

Zebrafish were bred and keep up in the Electronic Microscopy Section, Anatomical Institute "José Izquierdo," Universidad Central de Venezuela (Caracas, Venezuela), by an adjusted method (14). The fishes were preserved in 20-L tanks, previously filled with newly prepared filtered tap water (FTW), at $28^{\circ} \mathrm{C}$, pH 6.6 - 7.0, with 12 -h light/12-h dark cycle. For reproduction reasons, six to eight pairs of adult zebrafish were set up in 10-L tanks with a mesh and allowed to breed without restrictions. During the reproduction period, 100 and 150 eggs were collected per pair. They were gathered, washed and transferred to Petri dishes. Eggs containing dead or decreased quality larvae were discarded. The larvae were cleaned and well-arranged by stage of development $5 \mathrm{~d}$ after fertilization (dpf) to perform toxicity assays. The fish larvae were located in FTW into microtiter plates, and then the fractions achieved by the C-18 HPLC chromatography were ten larvae per well tested, with fraction concentrations of $0.76 \mu \mathrm{g} / 100 \mu \mathrm{L} / \mathrm{FTW}$. Negative controls with FTW were utilized.

\section{Larvae observation}

Fully alive larvae pictures were takenwith an Olympus IX-71 Series (Olympus, Japan) inverted microscope. Specific software to capture images (MetaMorph-Microscopy Automation \& Image Analysis Software) and a Sony SRS-PC71 device camera with microcolor filter, adapted to 200 squares/s with 40 $\mathrm{X}$ magnification that was fix to quantify the length of the images structures were used.

\section{Zebrafish larvae under toxicity analysis}

Inspection of the larvae under Tityus discrepans venom fractions toxicity was usually carried out in 24-well plates. Larvae at the $5 \mathrm{dpf}$ stage (weight of $5 \mathrm{dpf}$ larvae was $\sim 0.01 \mathrm{~g}$ ) were hoarded and transferred to assay wells (normally 10 larvae/well), by ten- der pipetting to reduce injury to the larvae. Then, its development was monitored hourly post-fertilization and visually inspected at room temperature, under a microscope equipped with a digital video camera. All abnormal morphological and performing changes, including lethality, were recorded and kept as exhaustive pictures and videos. Ten wells have been examined for each fraction, and the authors performed technical and biological replicates.

\section{Morphological modifications and larvae behavior}

Body larvae irregularities and motion comportments were visualized during earlyand late-stage of development. The observation was reiterated, in order to validate any detected harm, to confirm that the damages and conducts were reliable and reproducible. The injuries and the mobility behaviors were explicitly noted as "positive", when remarked in $>80 \%$ (i.e., 8 of 10 ) of tested larvae.

\section{Hemorrhages and thrombosis}

Looking for thrombus and/or hemorrhages presence, the larvae zebrafish ventricle and cardinal vein (cardiovascular system) was considered. It is accepted that hemorrhages and/or thrombosis originate from fissure of blood circulatory vessels in any organ.

\section{Cardiovascular evaluation}

Cardiac frequency (heart rate) (pulsation per minute: ppm) from ten 5 dpf zebrafish larvae were scattered into a microtitre plate, in which Tityus discrepans 1 and 2 venom fractions were dispensed and tested for $15,30,40$, and $60 \mathrm{~min}$ at room temperature and examined under a Olympus IX-71 Series microscope. After incubation, ventricular and atrial rates (ppm) were counted during $30 \mathrm{~s}$ with a stopwatch and a counter (7). The number of contractions was multiplied by two to calculate heart rate in pulsations per minute (7). Ten tests were taken, 
and their median was statistically considered. In the tests, the ppm for 1 and 2 Tityus discrepans venom fractions were measured up to equivalent normal control larvae under identical conditions.

\section{Statistics}

Statistical analyses were carried out employing an unpaired Student's t-test ("p $<0.05 ; * * \mathrm{p}<0.001)$.

\section{RESULTS}

\section{Protein concentration of the scorpion} Tityus discrepans venom by bicinchoninic acid

The Tityus discrepans venom protein concentration by BCA was $7.5 \mathrm{mg} / \mathrm{mL}$.

Meanwhile, the fractions 1 and 2 tested were 0.25 and $0.13 \mathrm{mg} / \mathrm{mL}$, respectively, assuming that $1 \mathrm{U}$ of absorbance/cm of wavelength at $280 \mathrm{~nm}$ corresponds to $1 \mathrm{mg}$ protein/mL (9).
Fractionation of the scorpion Tityus discrepans venom by HPLC

The Tityus discrepans venom was fractionated using the high-resolution chromatography method. In Fig. 1, well-defined fractions can be observed. Fractions 14 (now fraction 1) and 55 (now fraction 2), with retention times of $11.87 \mathrm{~min}$ and $25.58 \mathrm{~min}$, respectively, were chosen to perform in the zebrafish larvae the subsequent tests, such as it was stablished above.

\section{Electrophoretic profile of venom by $15 \%$ SDS-PAGE}

Fig. 2 shows the Tityus discrepans venom electrophoretic profiles. The distribution of protein bands occurred within gel regions corresponding to narrow range molecular masses. In Tityus discrepans crude venom $\sim 11$ protein bands were evident. The high intensity bands accorded with the $~$ $42,35,25,8$ and $3 \mathrm{kDa}$ molecular masses. Other lower intensity bands corresponded to

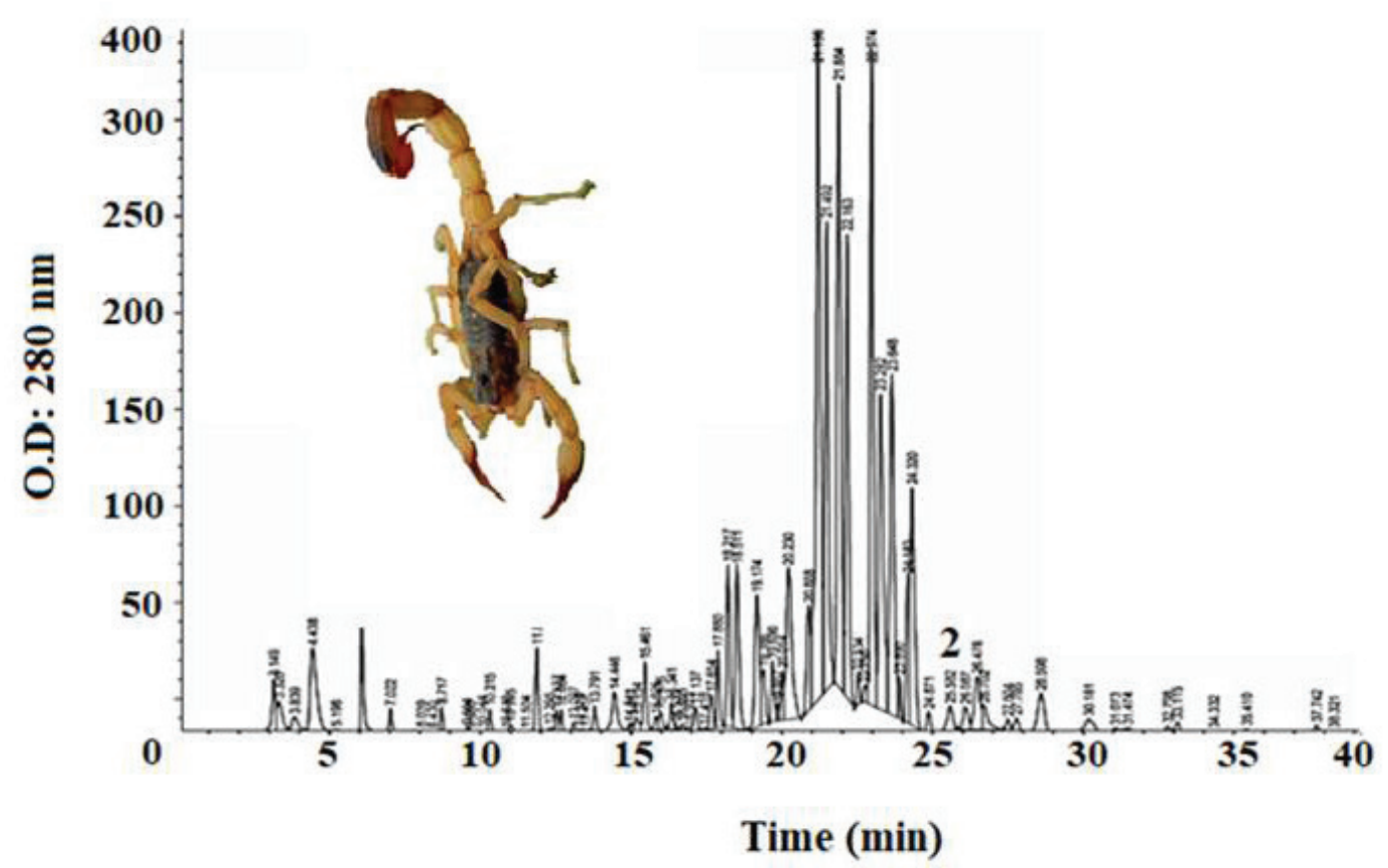

Fig. 1. Tityus discrepans venom separation by HPLC. Y axis indicates the absorbance at $280 \mathrm{~nm}$, the $\mathrm{X}$ axis the elusion time of the fractions. Fractions 14 (now fraction 1) and 55 (now fraction 2), with retention times of $11.87 \mathrm{~min}$ and $25.58 \mathrm{~min}$, respectively. 


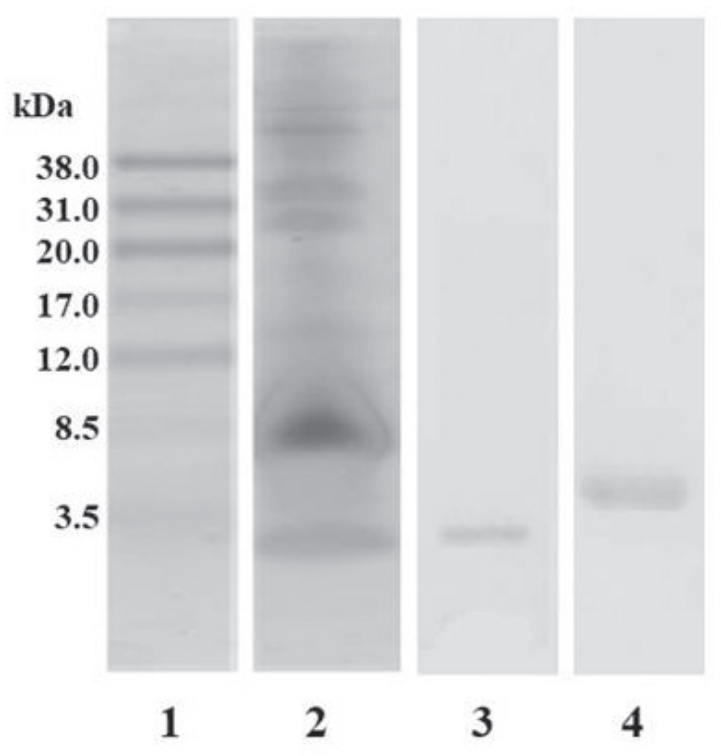

Fig. 2. SDS-PAGE (15\%) profile from Tityus discrepans crude venom stained with Coomassie blue. (1) "Low-range rainbow" molecular mass markers (38 to $3 \mathrm{kDa})$. (2) Tityus discrepans crude venom $(5 \mu \mathrm{g})$. (3) Fraction 1 $(5 \mu \hat{g})$. (4) Fraction 2 (5 $\mu \mathrm{g})$.

proteins up to $\sim 42 \mathrm{kDa}$. Fractions 1 and 2 showed a single band of $\sim 3$ and $\sim 5 \mathrm{kDa}$, respectively.

Lethality: determination of the $\mathrm{LD}_{50}$ of the Tityus discrepans crude venom

The $\mathrm{LD}_{50}$ of the Tityus discrepans crude venom tested in mice was $3.5 \mathrm{mg} / \mathrm{kg}$.

\section{Larvae observation}

From the relevant fractions (HPLC), the doses were prepared to be confronted by the larvae, and observed with an Olympus microscope, which allowed the analysis of their physical, organic and behavioral changes. A tool (Table I) was created to keep records of the analyses.

\section{Zebrafish larvae under toxicity analysis}

The purest fractions that had the highest amount of proteins were tested. Fractions 1 and 2 were chosen for study in the zebrafish model showing several and different effects (Table II and Figs. 3 and 4).
TABLE I

DATA RECORDING FOR ASSAY ANALYSIS.

\begin{tabular}{lcc}
\hline Fractions & Tested doses & $\begin{array}{c}\text { Observations } \\
(1 \mathrm{~h})\end{array}$ \\
Fraction 1 & $0.76 \mu \mathrm{g}$ & $\begin{array}{c}\text { Types of motion } \\
\text { Paralysis presence } \\
(0 \text { or }+)\end{array}$ \\
Fraction 2 & $0.76 \mu g$ & $\begin{array}{c}\text { Characteristic } \\
\text { of blood flow } \\
\text { Death }(0 \text { or }+) \\
\text { Other observations }\end{array}$ \\
\hline
\end{tabular}

TABLE II

RESULTS FROM MORPHOLOGICAL MODIFICATIONS AND BEHAVIOUR, OBTAINED

FROM THE ACTION OF Tityus discrepans FRACTIONS (1 AND 2) ON 10 ZEBRAFISH LARVAE, VIA OLYMPUS MICROSCOPE WITH PHASE CONTRAST VISION.

\begin{tabular}{|c|c|}
\hline $\begin{array}{c}\text { Fractions } \\
(0.76 \mu \mathrm{g} / \\
\text { larva })\end{array}$ & $\begin{array}{l}\text { Observations } \\
\text { (1h) }\end{array}$ \\
\hline Fraction 1 & $\begin{array}{c}\text { Circular movements } \\
\text { Circulatory paralysis } \\
\text { Decreased blood flow } \\
\text { Disseminated intravaseular } \\
\text { coagulation } \\
\text { Tremor } \\
\text { Death at } 40 \mathrm{~min}\end{array}$ \\
\hline Fraction 2 & $\begin{array}{c}\text { Alteration of circulation (late) } \\
\text { Little cardiac alteration } \\
\text { Detachment of the epithelium } \\
\text { Tremor } \\
\text { Death at } 60 \mathrm{~min}\end{array}$ \\
\hline
\end{tabular}

\section{Cardiac and circulatory thrombosis}

For untreated larvae, mortality and spontaneous changing dysfunction naturally happened at comparatively low frequency (approximately $<3 \%$ of larvae).

Larvae developing in vivo toxicity by Tityus discrepans fraction 1 showed after 15 min, visible internal organ damage, including thrombus formation in the ventricle and the cardinal veins (Fig. 5). This cardiac 


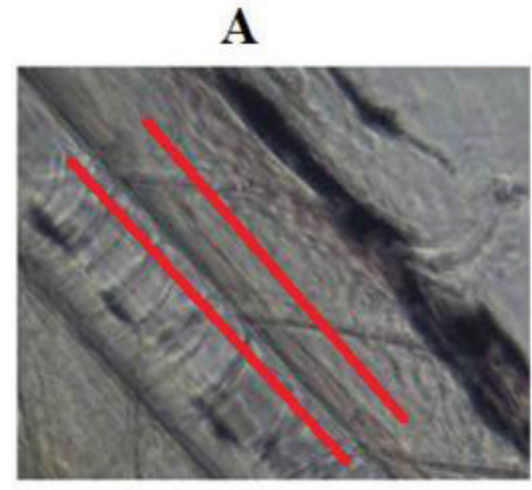

Normal control

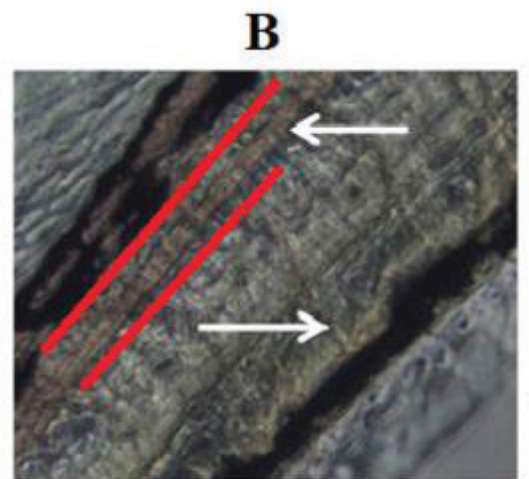

Fraction 1

Time (30 min)

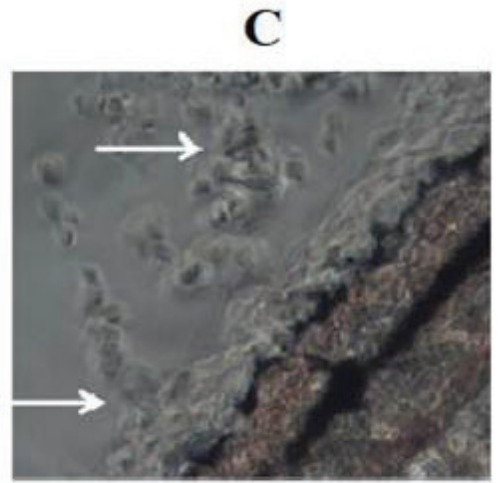

Fraction 2

Time (60 min)

Fig. 3. Microscopic observation of zebrafish larvae under Tityus discrepans fractions action (0.76 $\mu$ g) . (A) Normal control. (B) Fraction 1 showed an intravascular coagulation (arrows). (C) Fraction 2, an epithelial necrosis was palpable (arrows).

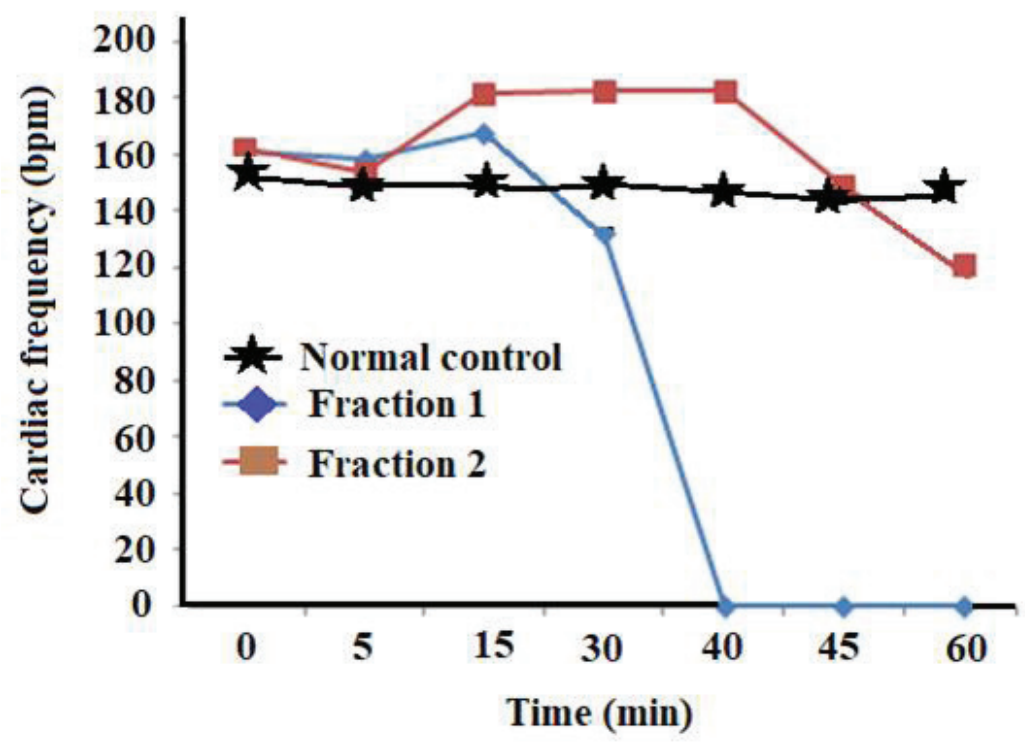

Fig. 4. Comparison of cardiac frequency of zebrafish larvae among Tityus discrepans fractions 1 (rhombus), fraction 2 (square) and normal control (star). The $\mathrm{X}$ axis represent time and the $\mathrm{Y}$ axis pulsations per minute.

thrombosis was evaluated using larvae in the presence of $0.76 \mu \mathrm{g}$ of Tityus discrepans fraction 1, in comparison with negative control (FTW-treated) samples (Fig. 5).

\section{Cardio-circulatory appraisal}

The larvae confronted with fraction 1, after 5 min presented a reduction in irrigation blood and intravascular coagulation (Fiǵ. 3). The larvae died past $40 \mathrm{~min}$. On the other hand, with respect to the fraction 2 , the effect on blood circulation was late, when compared with fraction 1 . However, after $30 \mathrm{~min}$ the blood circulation began to decrease, and at $60 \mathrm{~min}$, there was a necrotic detachment of the epithelium (Fig. 3B), and death of the 

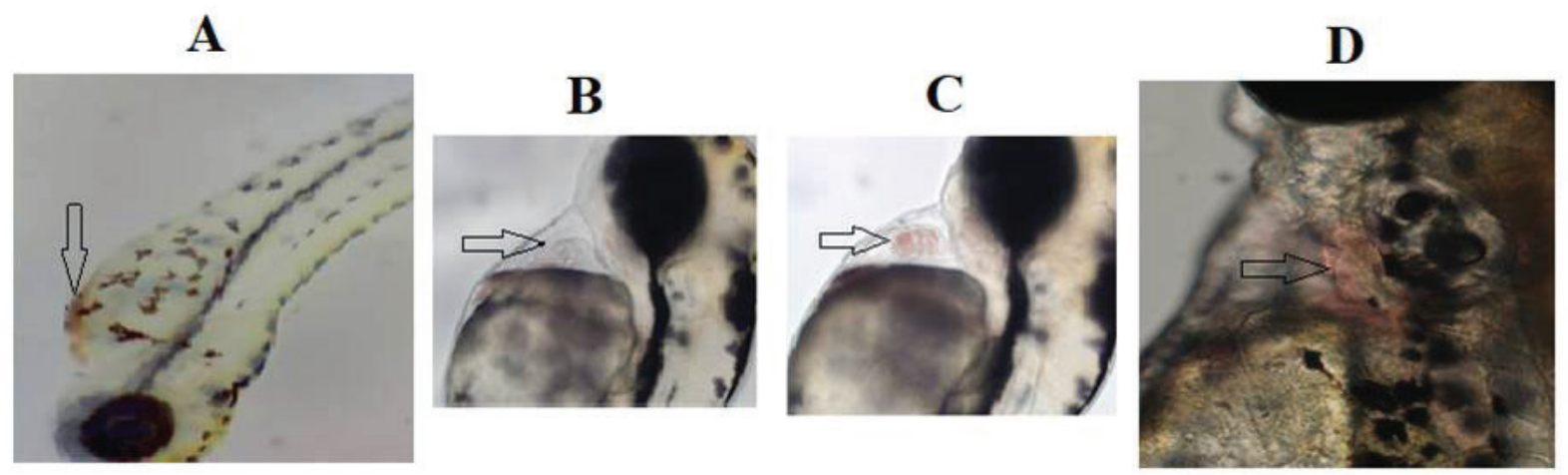

Fig. 5. Thrombolytic activity from Tityus discrepans fraction 1 . Images of the treatment of 5 dpf larvae with Td fraction $1(0.76 \mu \mathrm{g})$, from 0 to $40 \mathrm{~min}$, displayed "early-stage" (15 min) modifications, with evident thrombosis in the ventricle. (A) Low magnification of thrombus in the cardiac area (arrow); (B) Normal control; (C) Cardiac thrombus (arrow) Tityus discrepans fraction 1; (D) Magnified thrombus image (arrow) at $100 \mathrm{x}$.

larvae. The larvae confronted with fraction 1 , after 5 min presented an intense decrease in heart rate. Fraction 2 caused a more moderated decrease in heart rate (Fig. 4).

\section{DISCUSSION}

Utilization of the zebrafish model in toxicology research has increased in the latest years, converting it in one of the best advantageous and convenient systems for understanding parameters of toxins on the hemostatic and cardiovaseular systems (14). Even though there is considerable evolutionary separation between zebrafish and humans, significant genetic and phenotypic preservation in both systems have permitted substantial progresses in our understanding of how natural toxins act on the different organs and tissues of the human body. The potential of zebrafish, in the observation of toxins activities on the hemostasis and cardiovascular structures, allows for the possibility to carry out at in vivo real-time observations of these systems, and their altered functions, along with the simplicity. Similarly, the different toxins modifying specific hemostatic processes or cell alterations can be recognized and typified.
A scorpion uses its venom to paralyze and kill its prey (usually insects) that it is going to eat, and its gland takes approximately three weeks to replenish its venom. The venom is biologically composed of toxins with diverse actions, for instance: cardiotoxins, nephrotoxins, hemolytic toxins, phosphodiesterases, phospholipases, hyaluronidases, ǵlycosaminoglycans, histamine, serotonin, tryptophan, bradykinin-enhancing and cytokine-releasing peptides (15).

In the current work the Tityus discrepans venom was obtained from 42 scorpions, whose venom dry weight yield was $\mathbf{5 1 . 7}$ $\mathrm{mg}$, which represents $1.22 \mathrm{mg}$ of venom per milked scorpion. Similar results were recorded (16), when milking, under the same conditions, $92 T$. caripiensis scorpions, obtaining a dry weight of venom of $96.6 \mathrm{mg}$ that represented $1.05 \mathrm{mg}$ of venom per milked scorpion. Likewise, these data correlated with those described for the scorpion T. pachyurus from Colombia, which gave a yield between 0.3 and $1.0 \mathrm{mg}$ of venom per specimen (17). On the other hand, it has been described that the color of venom obtained by electrical stimulation is white, such as it was our venom and did not turn blue after milking. Contrastingly, the venom 
collected manually rapidly becomes blue after milking (18).

In the Tityus discrepans venom HPLC fractionation, around 60 well-defined fractions were observed; those with the highest concentration were those belonging to retention times in the range of 20 to 25 min. Previous studies (19) of Tityus discrepans venom fractionated with HPLC $(\sim 65$ fractions) had shown that the peaks elute at similar retention times, where there were groups of compounds with similar size and activity.

Fractions that eluted during the first 10 min had molecular masses between 20 and $200 \mathrm{kDa}$; among these are toxins that have Xa inhibitory factor, amidolytic and plasmin inhibitory activity (20). The toxins that elute between 10 and 30 min had masses between 3 and $5 \mathrm{kDa}$; In this range, there are toxins with activity on potassium channels $(21,22)$. The fractions that eluted between 30 and $40 \mathrm{~min}$ had masses ranging from 5 to $8 \mathrm{kDa}$; this range includes toxins capable of modulating sodium channels in the membrane (23). Less hydrophilic proteins with high molecular weights elute sometimes $>$ $40 \mathrm{~min}$; the latter contains a curarizing peptide TdFI33 and enzymes such as serine and metalloproteases $(20,21)$.

This venom is a mixture $\sim 80$ different toxins, mostly of low molecular masses, isolated and recognized by chromatography and electrophoresis. Opposition assays have proven their actions on the voltage-dependent ion channels (mainly $\mathrm{Na}+$, $\mathrm{Ca}++$, $\mathrm{K}+$ and $\mathrm{Cl}-$ ), and on excitable membranes (glandular, nervous and muscular tissue), transforming their ionic permeability, depolarizing them and yielding neurotransmitter discharges in the post-ganglionic endings, of the sympathetic and parasympathetic nervous system. However, non-all of these fractions are venomous to humans (24). Only about 10 act on mammals and 3 of these subtypes are toxic (containing between 61 and 62 amino acids). The venom is speedily absorbed, agreeing to the findings of several studies, since from the first 5 to 15 min obvious clinical signs of the action of the venom were observed (21).

In our study, when facing the selected Tityus discrepans venom fractions, numerous changes were observed in the organic structure and behavior of the specimens, such as circular movements, tremor, detachment of the epithelium, disseminated intravascular coagulation, decrease in heart rate and death. This gives us an indication of the effect of these fractions, especially in the circulatory system. The toxic effects of scorpion envenomation are probably due to a considerable discharge of sympathetic and parasympathetic neurotransmitters; the seriousness is associated to cardiac and hemodynamic alterations, with cardiogenic shock and pulmonary edema causative of the crucial causes of death (25).

It is also important to note that to date; no other studies are known to use the zebrafish model to assess the toxicity and lethality of the Tityus discrepans scorpion venom. However, we had assayed this methodology, characterizing a cardiotoxic effect in zebrafish larvae, produced by a toxin (Mutacytin-1) present in the venom of the Lachesis muta muta snake (14) and Bothrops venezuelensis venom. This toxin has coagulant activity (verified with the formation of a fibrin meshwork in platelet-poor human plasma and direct observation of clot formation in the heart of the animal model) and induces compromise of the cardiac system (decrease in cardiac frequency and output) (44).

Electrophoretic analysis of $T d$ venom by $15 \%$ SDS-PAGE indicated that the Tityus discrepans crude venom sample showed one major band of protein with molecular masses averaging around 8 to $10 \mathrm{kDa}$. D'Suze et al. (22) had described proteins in the Tityus discrepans venom of 3 and $5 \mathrm{kDa}$. According to Diaz et al. (23), they found proteins from 5 to $8 \mathrm{kDa}$ in the scorpion venom.

In the present work, the $\mathrm{LD}_{50}$ determination for $T d$ crude venom was of $3.5 \mathrm{mg} / \mathrm{kg}$, demonstrating high lethality by the intraper- 
itoneal route in C57/BL6 mice. When comparing the $\mathrm{LD}_{50}$ obtained in this work, with those detected $(2.5 \mathrm{mg} / \mathrm{kg})$ with the same species, by other authors $(11,26)$, differences in the levels of lethality were observed.

Concerning hemostatic and cardiocirculatory considerations, previous in vitro trials carried out in human plasmas, demonstrated that in the venom of Tityus discrepans an anti-procoagulant fractions exist $(27,28)$. This venom also contains compounds capable of degrading fibrinogen (28). Furthermore, this venom produces an activity similar to the Xa factor (procoagulant activity) (29) that was found in fraction 1 ; this finding is consistent with the synergy in amidolytic activity, described by the commercial Xa factor. Probably, the components with the activity similar to Xa factor present in the venom and fraction 1 , induced the shortening of the coagulation times. It is recognized that the $\alpha 2 \beta 1$ integrin situated on the exterior of platelets membranes are essential for thrombus formation on exposed collagen, at locations of vascular endothelium injury (30).

Toxicological responses of the heart to Tityus discrepans toxins were analyzed and interpreted, to establish the central axis of this research in the field of cardiotoxicity. The autonomous innervation of the heart regulates the contraction and the force of cardiac muscle. Catecholamines, released by sympathetic stimulation produce the cardiac chronotropic action (accelerating action), but the inotropic action is the force of cardiac contraction, which is controlled by the $B$-adrenergic receptors that are essential for sustaining the rate and strength of contraction of the heart muscle (31). While the adrenergic stimulus in supporting heart rate has been described in adult zebrafish, the precise responsibility of adrenergic regulation in zebrafish larvae is still poorly known. Several authors $(32,33)$ proposed that zebrafish larvae start to display a chronotropic response to adrenergic agonists at 4 or 6-day post-fertilization, since at that time zebra- fish larvae have $\beta 1$ adrenergic and $\beta 2$ adrenergic receptors, both associated to the increase in chronotropic and inotropic actions of the cardiac muscle.

The Tityus discrepans fraction 1 induced a severe decrease in the cardiac frequency (negative chronotropic action) leading the larvae to death. Fraction 2 also presented a negative chronotropic effect, but less intense than fraction 1 . We cannot determine whether the activity of both toxins have a direct effect on the $\beta 1$ adrenergic and 132 adrenergic receptors, both linked to increased chronotropism and inotropism of the cardiac muscle. These actions are due to the stimulating action on Protein G, which increases adenyl cyclase activity, causing high levels of cyclic AMP (34-37). Gibbins (38) has suggested that the principal factor to take in consideration about the cardiotoxic effect has been the modulation of heart frequency that can be regularly measured by a direct optical examination, by video-edge detection systems.

It has been reported that the early clinical signs are principally occasioned by venom-induced adrenergic and cholinergic effects $(30,39)$. Adrenergíc expressions are secondary to catecholamine discharge, which include cardiac failure and arrhythmias, tachycardia, arterial hypertension and shock. Symptomatology usually starts with further transient parasympathetic stimulation. However, severity, on the other hand, is largely established by the continuing impacts of high eatecholamine concentrations in the cardiovascular system (40-42).

Finally, we have evidenced the usefulness of this kind of in vivo assay estimating histologically and functionally zebrafish hearts in real-time, which allowed the evaluation of responses to toxins in the short and medium term. We want to propose the use of the zebrafish model, to evaluate the scorpion toxins on the cardiac system, trying to extrapolate the observed damages to that occurring in humans, all through many epidemiological studies (43). 


\section{ACKNOWLEDGMENTS}

We acknowledge the use of the Zebrafish Core Facility of the Laboratorio de Microscopía Electronica, Instituto Anatómico de la Universidad Central de Venezuela. This study was supported by the Funding grant from the Science and Technology Fund (FONACIT) programs (PEI 201400352) (Universidad Central de Venezuela, Dr. A. Rodríguez-Acosta).

\section{REFERENCES}

1. Rojas-Muñoz A, Rajadhyksha S, Gilmour D, van Bebber F, Antos C, Rodríguez- Esteban C, Nüsslein-Volhard C, IzpisúaBelmonte JC. ErbB2 and ErbB3 regulate amputation-induced proliferation and migration during vertebrate regeneration. Develop Biol 2009; 327:177-190.

2. Ghilardi A, Diana A, Prosperi L, Del Giacco L. Expression pattern of the small muscle protein, $X$-linked (smpx) gene during zebrafish embryonic and larval developmental stages. Gene Exp Pat 2020; 36: 119110.

3. Chan J, Bayliss PE, Wood JM, Roberts TM. Dissection of angiogenic signalling in zebrafish using a chemical genetic approach. Cancer Cell 2002; 1: 257-267.

4. MacRae CA, Peterson RT. Zebrafish as tools for drug discovery. Nat Rev Drug Dise 2015; 14: 721-731.

5. Pichler FB, Laurenson S, Williams LC, Dodd A, Copp BR, Love DR. Chemical discovery and global gene expression analysis in zebrafish. Nat Biotech 2003; 21: 879-883.

6. Sand S, von Rosen D, Victorin K, Filipsson AF., Identification of a critical dose level for risk assessment: developments in benchmark dose analysis of continuous endpoints. Toxicol Sei 2006; 90: 241-251.

7. Damico L. Zebrafish: Methods for Assessing Drug Safety and Toxicity. Assessment of drug-induced cardiotoxicity in zebrafish, New Jersey, Ny, USA: John Wiley and Sons, Inc; 2012, p. 45-54.

8. Pifano F. Investigación y docencia en medicina tropical. Arch Venez Med Trop Parasitol Med 1961;4: 1-203.
9. Stoscheck CM. Quantitation of protein. Meth Enzymol 1990; 182: 50-68.

10. Spearman-Kärber, F. Alternative Methods of Analysis for Quantal Responses. In: Statistical Method in Biological Assay. London: Finney DJ, Charles Griffin \& Co Ltd; 1978.

11. Blanco M, Rodríguez-Acosta A, Strauss M, Pulido-Méndez M, Rodríguez C, González L. Pancreas ultrastructural alterations in mice inoculated with Tityus discrepans (Buthidae) venom. Submic J Cytol Pathol 1999; 31, 51-56.

12. World Health Organization: Progress in the characterization of venoms and standardization of antivenoms. Geneva: WHO offset Publication 1981; 1-58.

13. Laemmli UK. Cleavage of structural proteins during the assembly of the head of bacteriophage T4. Nature 1970; 227: 680-685.

14. Zanotty Y, Álvarez M, Perdomo L, Sanchez EE, Girón ME, Suntravat M, Montero Y, Medina R, Navarrete LF, Rodríguez-Acosta A. Mutacytin-1, a new C-Type Lectin-Like protein from the Venezuelan cuaima ( $\mathrm{La}$ chesis muta muta Linnaeus, 1766) (Serpentes: Viperidae) snake venom inducing cardiotoxicity in developing zebrafish (Danio rerio) embryos. Zebrafish 2019; 16: 379-387.

15. De Roodt A. Veneno de escorpiones (alacranes) y envenenamiento. Acta Bioquím Clín Latinoamericana 2015; 49: 55-71.

16. Parrilla-Alvarez $P$, D'Suze G, Quiroga M, Rodriguez-Acosta A, Sevcik C. Effects of formalinization on the immuno-pharmacological characteristics of the venom of the Tityus Scorpions and cross-reactivity between these venoms. J Venom Anim Toxins 1999; 5: 110.

17. Barona J, Batista V, Zamudio F, GómezLagunas F, Wanke E, Otero R, Possani LD. Proteomic analysis of the venom and characterization of toxins specific for $\mathrm{Na}+$ - and $\mathrm{K}+$ - channels from the Colombian scorpion Tityus pachyurus. Biochim Biophys Acta 2006; 7: 76-84.

18. Oukkache N, Chgoury F, Lalaoui M, Cano AA, Ghalim N. Comparison between two methods of scorpion venom milking in Moroceo. J Venom Anim Toxins incl Trop Dis 2013; 19: 5 . 
19. Joya G, Salazar V, Rosales A, Sevcik C, Visbal G, Ferreira A, D'Suze G. Scorpion toxins modify phytopathogenic fungus physioloǵy. a possible source of new fungicides. J Agric Food Chem 2011; 2011: 6327-6337.

20. Brazón P, D’Suze G, Errico M, Sevcik C, Arocha-Pinango C, Guerrero B. Discreplasminin, a plasmin inhibitor isolated from Tityus discrepans scorpion venom. Arch Toxicol 2009; 83: 669- 678.

21. Batista C, D'Suze G, Gomez F, Zamudio F, Seveik C, Possani L. Proteomic analysisof Tityus discrepans scorpion venom and aminoacid sequence of noveltoxins. Proteomics 2006; 23: 3718-3727.

22. D'Suze G, Zamudio F, Gomez-Lagunas F, Possani, L. A novel Kp channel blocking toxin from Tityus discrepans scorpion venom. FEBS Letters 1999; 456: 146-148.

23. Díaz P, D'Suze G, Salazar V, Sevcik C, Shannon J, Sherman E, Fox, J. Antibacterial activity of six novel peptides from Tityus discrepans scorpion venom. a fluorescent probe study of microbial membrane Nap permeability changes. Toxicon 2009; 54: 802-817.

24. Isbister G, Bawaskar H. Scorpion Envenomation. New Enǵland J Med 2014; 5: 457 463.

25. Gwee MCE, Nirthanan S, Khoo HE, Gopalakrisshnakone P, Kini RM, Cheah L. Autonomic effects of some scorpion venoms and toxins. Clin Experim Pharm Physiol 2002; 29: 795-781.

26. Borges A, Tsushima RG, Backx PH. Antibodies against Tityus discrepans venom do not abolish the effect of Tityus serrulatus venom on the rat sodium and potassium channels. Toxicon 1999; 37: 867-881.

27. D'Suze G, Seveik C, Corona M, Zamudio F, Batista C, Coronas F, Possani L. Ardiscretin a novel arthropod-selective toxin from Tityus discrepans scorpion venom. Toxicon 2004; 43: 263-272.

28. Brazon J, Guerrero B, D'Suze G, Sevcik C. Anticoagulant and factor Xa-like activities of Tityus discrepans scorpion venom. Acta Toxicol Arǵentina 2013; 1: 26-32.

29. Shan K, Bick RJ, Poindexter BJ, Nagueh SF, Shimoni S, Verani MS, Keng F, Reardon MJ, Letsou GV, Howell JF, Zoghbi WA. Altered adrenergic receptor density in myocardial hibernation in humans: A possible mechanism of depressed myocardial function. Circulation 2000; 102: 2599 2606.

30. Mazzei-de-Dàvila CA, Dàvila DF, Donis JH, de-Bellabarba GA, Vilarreal V, Barboza JS. Sympathetic nervous system activation, antivenin administration and cardiovascular manifestations of scorpion envenomation. Toxicon 2002; 40: 1339-1346.

31. Schwerte T, Prem C, Mairösl A, Pelster B. Development of the sympatho-vagal balance in the cardiovascular system in zebrafish (Danio rerio) characterized by power spectrum and classical signal analysis. J Exp Biol 2006; 209(Pt 6), 1093-1100.

32. Bagatto $\mathbf{B}$, Burggiren $\mathbf{W}$. A three-dimensional functional assessment of heart and vessel development in the larva of the zebrafish (Danio rerio) Physiol Biochem Zool 2005; 79: 194-201.

33. Abdelilah S, Mountcastle-Shah E, Harvey M., Solnica-Krezel L., Schier AF, Stemple DL, Malicki J, Neuhauss SC, Zwartkruis F, Stainier DY, Ranǵini Z, Driever W. Mutations affecting neural survival in the zebrafish Danio rerio. Development 1996; 123: 217-227.

34. Frezza E, Amans TM, Martin J. Allosteric Inhibition of adenylyl cyclase type 5 by GProtein: a molecular dynamics study. Biomolecules 2020; 10: 1330.

35. Laudette $M$, Formoso $K$, Lezoualch $F$. GRKs and Epac1 interaction in cardiac remodelling and heart fFailure. Cells 2021; 10: E154.

36. Parker T, Libourel PA, Hetheridge MJ, Cumming RI, Sutcliffe TP, Goonesinghe AC, Jonathan SB, Stewart FO, Yann Ch, Matthew JW. A multi-endpoint in vivo larval zebrafish (Danio rerio) model for the assessment of integrated cardiovascular function. J Pharmacol Toxicol Met 2011; 69: 30-38.

37. Schwerte T, Fritsche R. Understanding cardiovascular physiology in zebrafish and $\mathrm{Xe}$ nopus larvae: the use of microtechniques. Comp Biochem Physiol Part A: Mol Integ Physiol 2003; 135: 131-145.

38. Gibbins JM. Platelet adhesion signalling and the regulation of thrombus formation. J Cell Sci 2004; 117: 3415-3425. 
39. Teixeira AL, Fontoura BF, Freire-Maia L, Machado CR, Camargo ER, Teixeira MM. Evidence for a direct action of Tityus serrulatus scorpion venom on the cardiac muscle. Toxicon 2001; 39: 703-709.

40. Amaral CF, Lopes JA, Magalhães RA, deRezende NA. Electrocardioǵraphic, enzymatic and echocardiographic evidence of myocardial damage after Tityus serrulatus scorpion poisoning. Am J Cardiol 1991; 67: 655-657.

41. Freire-Maia L, Campos JA. Pathophysiology and treatment of scorpion poisoning. Natural Toxins, Characterization, Pharmacology and Therapeutics. In: Ownby CL, Odell GV. (Eds.), Proceedings of the 9 thWorld Congress on Animal, Plant and Microbial Toxins. Oxford UK; Pergamon Press Still Water, Oklahoma USA; 1989; 139-159.
42. Cupo P. Clinical update on scorpion envenoming. J Brazil Soc Trop Med 2015; 48: 642-649.

43. De Sousa L, Borges A, De Sousa-Insana E, Vásquez-Suárez A. Mortality caused by venomous animals in Venezuela (2000-2009): A new epidemiological pattern. Biomedica. 2021; 41: 29-40.

44. Raventos J, Torres R, Alvarez M, Girón ME, Perdomo L, Rodriguez-Acosta A. Aspectos bioquímicos y funcionales de la acción tóxica de proteasas del veneno de la serpiente tigra mariposa (Bothrops venezuelensis) sobre las estructuras anatómicas del pez cebra (Danio rerio). Saber UDO. 2018; 30:103-114. 